\title{
LUNG FIBROSIS AND EXPOSURE TO WOOD DUSTS: TWO CASES REPORT AND REVIEW OF THE LITERATURE
}

\author{
ZWŁÓKNIENIE PŁUC A NARAŻENIE NA PYŁ DREWNA - \\ OPISY DWÓCH PRZYPADKÓW I PRZEGLĄD LITERATURY
}

Italian National Health Service, Local Health Unit of Parma, Langhirano, Italy

Occupational Health and Safety Unit, Department of Prevention

\begin{abstract}
Introduction: Increasing evidence suggests that idiopathic pulmonary fibrosis (IPF) occurs more often in subjects previously exposed to wood dusts than in non-exposed subjects. Here we report 2 cases of the IPF among workers prolongedly exposed to high levels of hardwood dusts. Cases report: The case No. 1: An 83 year-old male former smoker, retired joiner developed mild dyspnoea and chronic dry cough over the period preceding the examination. Pulmonary function tests (PFT) identified a mild restrictive pattern and diffusion capacity for carbon dioxide $\left(\mathrm{CO}_{2}\right)$ that was severely impaired (57\% of predicted value). High resolution computer tomography (HRCT) identified bilateral, subpleural basal reticular opacities in honeycombing, without any nodules or ground-glass opacities. The case No. 2: A 73 year-old male retired joiner, never smoker, presented a 3-year history of progressive breathlessness and non-productive cough in mild hypoxemia. Pulmonary function tests suggested a moderate restrictive pattern in severely impaired diffusion capacity for $\mathrm{CO}_{2}(54 \%$ of predicted value). High resolution computer tomography identified diffuse peripheral reticular opacities and honeycombing of lower fields, with apico-basilar gradient. Both cases received diagnosis of the idiopathic pulmonary fibrosis. Discussion: The pulmonary fibrosis is a common feature of several diseases and may be induced by inflammatory disorders following inhalation of organic and inorganic dusts (e.g., asbestos, silica), and several reports suggest that many cases of the IPF may be in fact secondary to occupational dust exposure as in the case reports we present here. Conclusions: Occupational exposure to wood dusts may be a risk factor for the IPF. Unfortunately, exposure reconstruction is frequently inconsistent and anamnesis often misses other causes of the pulmonary fibrosis (e.g., extrinsic allergic alveolitis). Med Pr 2015;66(5):739-747
\end{abstract}

Key words: idiopathic pulmonary fibrosis, extrinsic allergic alveolitis, pneumoconiosis, pulmonary diffusing capacity, tomography

\section{STRESZCZENIE}

Wstęp: Coraz więcej dowodów wskazuje na częstsze występowanie samoistnego zwłóknienia płuc (idiopathic pulmonary fibrosis - IPF) u osób wcześniej narażonych na pyły drewna niż u osób nienarażonych na nie. Niniejszy artykuł przedstawia 2 przypadki IPF u pracowników długotrwale eksponowanych na wysokie stężenia pyłu drewna. Opis przypadków: Przypadek nr 1: U 83-letniego mężczyzny, byłego palacza i emerytowanego stolarza, w ciągu 6 miesięcy poprzedzających badanie rozwinęły się lekka duszność oraz przewlekły suchy kaszel. Badania czynnościowe płuc wykazały łagodne zaburzenia wentylacji typu restrykcyjnego oraz poważne upośledzenie dyfuzji dwutlenku węgla $\left(\mathrm{CO}_{2}\right)(57 \%$ wartości prognozowanej), natomiast tomografia komputerowa wysokiej rozdzielczości - obustronne podopłucnowe siateczkowate zacienienia u podstawy płuc w postaci obrazu plastra miodu, bez żadnych guzków ani zacienień typu matowej szyby. Przypadek nr 2: Badania czynnościowe płuc 73-letniego mężczyzny, nigdy nie palącego emerytowanego stolarza, z postępującą od 3 lat dusznością, suchym kaszlem oraz łagodną hipoksemią, wykazały umiarkowane zaburzenia wentylacji typu restrykcyjnego oraz poważne upośledzenie dyfuzji $\mathrm{CO}_{2}$ (54\% przewidywanej wartości), natomiast tomografia komputerowa o wysokiej rozdzielczości - rozproszone obwodowe siateczkowate zacienienia oraz obraz plastra miodu w dolnych polach ze szczytowo-podstawnym gradientem. W obu przypadkach zdiagnozowano samoistne zwłóknienie płuc. Omówienie: Zwłóknienie płuc jest wspólną cechą kilku chorób i może być wywołane przez procesy zapalne wskutek wdychania organicznych lub nieorganicznych pyłów (np. azbestu, krzemionki). Wiele doniesień, w tym przedstawione w niniejszej pracy, wskazuje na liczne przypadki IPF, w których etiologii narażenie zawodowe na pyły miało charakter drugorzędny. Wnioski: Narażenie zawodowe na pyły drewna jest czynnikiem ryzyka występowania IPF. Niestety odtworzenie rzeczywistej ekspozycji zazwyczaj jest trudne, a przeprowadzany wywiad często pomija pozostałe przyczyny powstania zwłóknienia płuc (np. alergiczne zapalenie pęcherzyków płucnych). Med. Pr. 2015;66(5):739-747

Słowa kluczowe: samoistne zwłóknienie płuc, zewnątrzpochodne alergiczne zapalenie pęcherzyków płucnych, pylica płuc, pojemność dyfuzyjna płuc, tomografia

Corresponding author / Autor do korespondencji: Matteo Riccò, Italian National Health Service,

Local Health Unit of Parma, Occupational Health and Safety Unit, Department of Prevention,

Via Roma 42, 43010 Langhirano, Italy, e-mail: mricco2000@gmail.com

Received: November 19, 2014, accepted: February 12, 2015 


\section{INTRODUCTION}

More than 3.5 million European people (2\% of the total workforce) are professionally exposed to wood dust (WD). Wood dust is mainly composed of cellulose (40-50\%), polyoses and lignin, with large differences in the exact composition depending on the 3 species processed. In particular, angiosperm wood (or hardwood) is generally denser than gymnosperm wood (or softwood), and dust produced during its processing is more fine and abundant [1].

Occupational exposure to WDs is very variable in terms of total amount and particle size: whereas older machine tools more frequently produce coarse particles of aerodynamic diameter $>100 \mu \mathrm{m}$ up to some millimetre (usually intercepted by nasal respiratory mucosa); high-speed units emit large amounts of particles with aerodynamic diameter of $10-100 \mu \mathrm{m}$, and also $<10 \mu \mathrm{m}$, that are able to interact with a lower respiratory tract. In general, this heterogeneity explains why occupational exposure to WDs has been shown to be associated with a variety of health effects and several disorders of all aerodigestive tracts: sinonasal cancer, asthma, chronic bronchitis, emphysema, extrinsic allergic alveolitis [2-4].

Moreover, a continuously increasing base of evidence associates exposure to WDs to interstitial lung disorders (ILD), such as the pulmonary fibrosis, and in particular the idiopathic pulmonary fibrosis (IPF) [5-7].

The idiopathic pulmonary fibrosis (IPF) is a specific form of chronic, progressive interstitial pneumonia marked by fibrosis of the lungs. It typically presents itself in persons aged over 50 years old, with preponderance in men and previous or current smokers. Its definition requires the exclusion of other forms of the ILD associated with environmental exposure, medication or systemic disease, the presence of a pattern of the usual interstitial pneumonia (UIP) on high resolution computer tomography (HRCT) in patients not subjected to surgical lung biopsy and/or specific combination of the HRCT and surgical lung biopsy pattern in patients subjected to surgical lung biopsy $[8,9]$.

Epidemiological data suggests that the IPF may be the first or the second most commonly ILD (17-86\%) and its incidence is globally increasing, estimated between 4.6 and 10.7 cases/100 000 cases per year, with prevalent estimates varying from 2 to 42.7 cases/100 000 in the general population, depending on the case definition that is used $[8,10]$. Age standardized mortality ranges between 4 and 10/100 000 with an overall 2-3\% increase annually in the last decade. Clinically, the IPF is characterised by progressive worsening of dyspnoea and lung function, with a high prevalence of patients requiring long-term oxygen therapy and, in general, dismal prognosis. Recent epidemiological data suggests a 5 -year mortality of $50-70 \%$, with the IPFrelated deaths in Europe estimated between 28000 and 65000 for 2014 [8,11].

Since the early 90 s observational studies have suggested that inhaled dusts, and in particular wood dusts, may contribute up to $12 \%$ of total cases of the IPF [5,6,10-13]. In 1990, a British case control study with lifetime occupational data obtained from

Table 1. Case control studies of occupational exposure to wood dusts (WDs) and meta-analysis of risk for idiopathic pulmonary fibrosis (IPF) Tabela 1. Badania kliniczno-kontrolne dotyczące samoistnego zwłóknienia płuc i narażenia zawodowego na pyły drewna oraz metaanaliza ryzyka IPF

\begin{tabular}{|c|c|c|c|c|c|c|}
\hline \multirow{2}{*}{$\begin{array}{c}\text { References } \\
\text { Piśmiennictwo }\end{array}$} & \multirow{2}{*}{$\begin{array}{l}\text { Year of study } \\
\text { Rok badania }\end{array}$} & \multicolumn{2}{|c|}{$\begin{array}{l}\text { Exposed group } \\
\qquad(\mathrm{N}=860) \\
{[\mathrm{n}]}\end{array}$} & \multicolumn{2}{|c|}{$\begin{array}{l}\text { Non-exposed group } \\
\qquad \begin{array}{c}\mathrm{N}=2190) \\
{[\mathrm{n}]}\end{array}\end{array}$} & \multirow{2}{*}{$\begin{array}{c}\text { OR } \\
(95 \% \mathrm{CI})\end{array}$} \\
\hline & & $\begin{array}{c}\text { with IPF } \\
\text { z IPF }\end{array}$ & $\begin{array}{c}\text { total } \\
\text { ogółem }\end{array}$ & $\begin{array}{c}\text { with IPF } \\
\text { z IPF }\end{array}$ & $\begin{array}{c}\text { total } \\
\text { ogółem }\end{array}$ & \\
\hline Scott et al. [14] & 1990 & 6 & 40 & 5 & 106 & $2.94(0.87-9.90)$ \\
\hline Hubbard et al. [6] & 1996 & 18 & 218 & 16 & 569 & $1.71(1.01-2.92)$ \\
\hline Baumgartner et al. [7] & 2000 & 20 & 248 & 29 & 491 & $1.60(0.80-3.30)$ \\
\hline Miyake et al. [18] & 2005 & 12 & 102 & 0 & 59 & $6.71(0.37-123.59)$ \\
\hline Gustafson et al. [15] & 2007 & 22 & 140 & 30 & 757 & $1.90(1.12-3.15)$ \\
\hline Awadalla et al. [17] & 2012 & 14 & 95 & 7 & 114 & $2.71(1.01-7.37)$ \\
\hline
\end{tabular}

OR - odds ratio / iloraz szans, CI - confidence interval / przedział ufności, $\mathrm{I}^{2}$ - percentage rate of total variation across studies that is due to heterogeneity rather than coincidence / procent całkowitej zmienności uwzględniający heterogeniczność analizowanych badań. 
a mailed questionnaire identified a substantially but not significantly higher risk for the IPF in subjects exposed to WDs (odds ratio $(\mathrm{OR})=2.94,95 \%$ confidence interval (CI): 0.87-9.9) [14]. A subsequent, larger followup study evidenced an increased risk for the IFP among workers exposed to WDs (OR $=1.71,95 \% \mathrm{CI}$ : $1.01-$ $2.92, \mathrm{p}=0.048$, when exposure was explored through a questionnaire; and 2.22, 95\% CI: $1.26-3.91$ for interview data), with a significant exposure-response relation (OR per work-year of exposure $=1.12$, 95\% CI: 1.02-1.24, $\mathrm{p}=0.020$ ) [6] and such results were consistent with several other studies in other countries [7,15-18] (Table 1).

Eventually, a meta-analysis by Taskar and Coultas identified the odds ratio for the IPF in WDs exposure at 1.94 (95\% CI: 1.32-2.81) [19] and a more recent mortality study identified the OR at 5.3 (95\% CI: 1.223.8) with a Proportional Mortality Rate (PMR) of 4.5 (95\% CI: 1.2-11.6) for workers employed in "wood buildings and mobile homes" [20].

Several European countries, but not Italy, have therefore recognized the pulmonary fibrosis (PF) among workers exposed to WDs as an occupational disease: here we present two case reports of the IPF among the subjects who experienced a long-time professional exposure to hardwood dusts, which was identified and documented in absence of other risk factors for the ILD.

\section{CASE NO. 1}

An 83 year-old Caucasian male retired joiner presented for evaluation of a slowly insurgent mild dyspnoea associated with chronic dry cough over the preceding 6 months. His past history was negative for allergic disorders and respiratory diseases. He was a former smoker as he had quitted smoking in the past 30 years (13.5 packs a year).

His occupational history was significant for work in a furniture industry when he was 18-63 years of age. He spent 8-10 h/day regularly exposed to wood dusts while sawing, filing and polishing wood, as a specialized mahogany joiner. He described the working environment as being very dusty, poorly aerated, but several technical reports (available for the later years) suggested an exposure between $3.8-5 \mathrm{mg} / \mathrm{m}^{3}$, lower than more recent reference values (Italian Legislative Decree No. 60/2000; TLV-TWA $5 \mathrm{mg} / \mathrm{m}^{3}$ ). He did not use any protective respiratory masks. He denied mining, construction, or silica- and asbestos-related occupations.

On physical examination, he showed a barrel chest with inspiratory crackles at lower lung fields and without finger clubbing or signs of cyanosis. He had normal vital signs (arterial blood pressure: 135/85 mm Hg, heart rate: 80 beats per minute) but pulse oximetry

b)
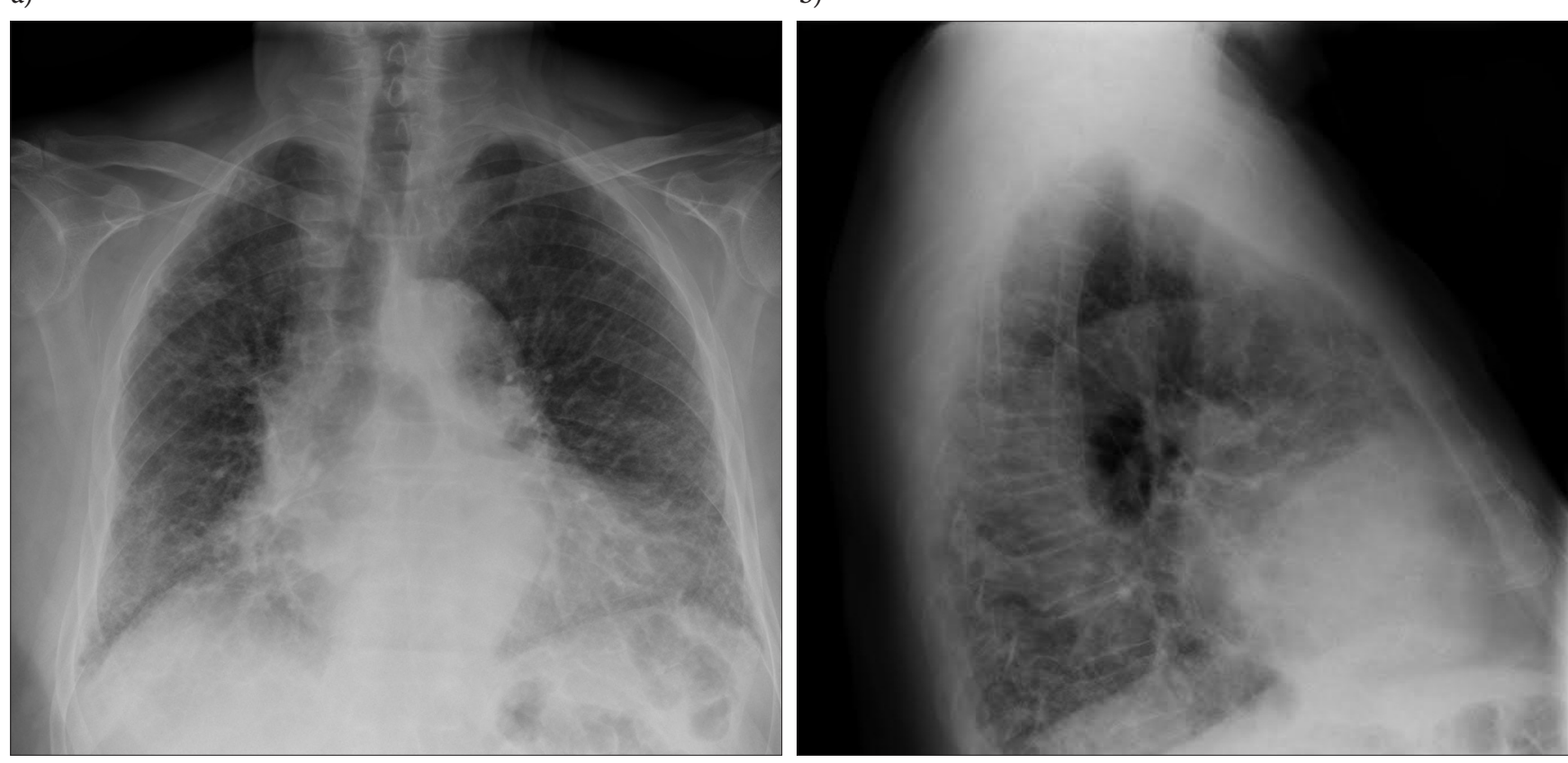

Reticular peripheral opacities predominant at lower lung fields / W dolnych polach płucnych dominują obwodowe siateczkowate zaciemnienia.

Photo 1. Chest radiography: a) posteroanterior view, b) lateral view - case No. 1

Foto. 1. Zdjęcie rentgenowskie klatki piersiowej: a) rzut tylno-przedni, b) rzut boczny - przypadek nr 1 
a)

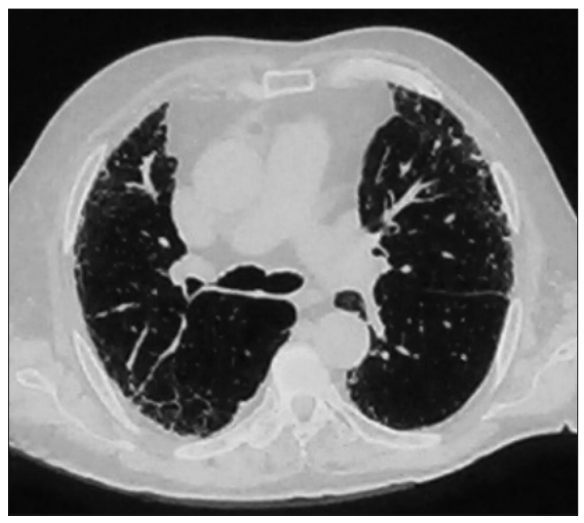

b)

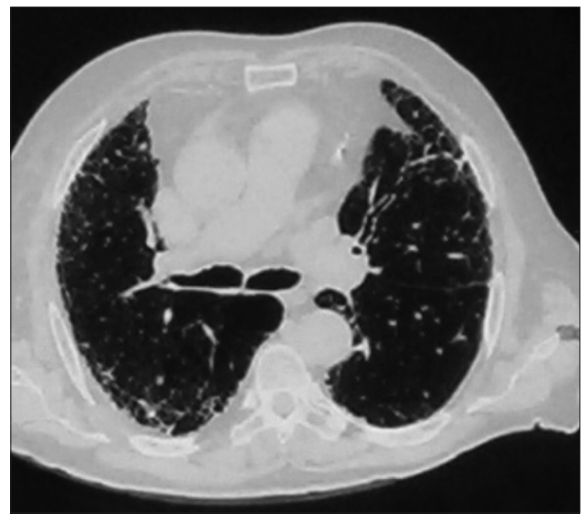

c)

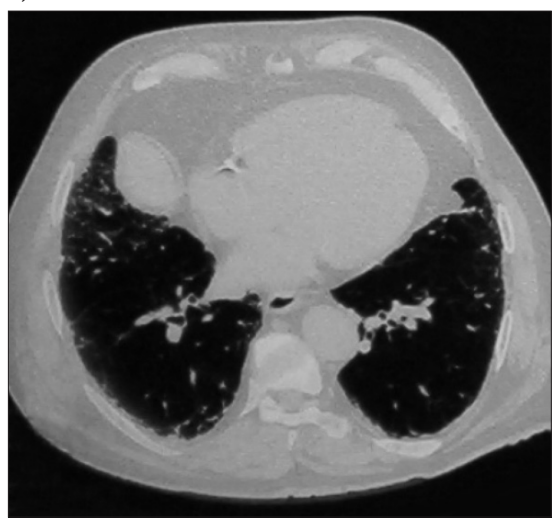

Selected axial slices through the lower lung fields $(\mathrm{a}-\mathrm{c})$ show bilateral, subpleural reticular opacities at lower fields. Traction bronchiectasis and honeycombing, in absence of any nodules or ground-glass opacities were more evident in the lower slices (b and c) whereas in the upper lobes (a) signs of emphysema without any significant air entrapment were remarkable / Wybrane przekroje osiowe dolnych pól płucnych (a-c) pokazują podopłucnowe siateczkowate zacienienia. Rozstrzenie i objawy plastra miodu, przy braku guzków lub ognisk typu matowej szyby, są bardziej widoczne na dolnych przekrojach (b i c), natomiast oznaki rozedmy bez znacznych pęcherzy powietrza - na przekroju przez górne płaty (a).

Photo 2. High resolution computer tomography (HRCT) - case No. 1

Fot. 2. Tomografia komputerowa o wysokiej rozdzielczości - przypadek nr 1

was steadily between $92 \%$ and $95 \%$ at rest. Routine laboratory exams revealed a complete blood count and blood chemistry panel that were normal in general, but blood gas evaluation reported compensated respiratory alkalosis $\left(\mathrm{pH}=7.433 ; \mathrm{pCO}_{2}=36.8 \mathrm{~mm} \mathrm{Hg}\right.$; $\left.\mathrm{pO}_{2}=86 \mathrm{~mm} \mathrm{Hg} ; \mathrm{HCO}_{3}^{-}=24.9 \mathrm{mmol} / \mathrm{l}\right)$. Pulmonary function tests showed a mild restrictive pattern (forced vital capacity $(\mathrm{FVC})=3.39 \mathrm{l}-102 \%$ of predicted value; forced expiratory volume in $1 \mathrm{~s}\left(\mathrm{FEV}_{1}\right)=2.64-109 \%$; $\mathrm{FEV}_{1} / \mathrm{FVC}=78 \%$; peak expiratory flow rate $(\mathrm{PEFR})=10.36 \mathrm{l} / \mathrm{s}-147 \%$, total lung capacity $($ TLC) $=4.941-75 \%$; residual volume $(\mathrm{RV})=1.491-52 \%$; expiratory reserve volume $(E R V)=1.781-217 \%)$ and diffusion capacity for $\mathrm{CO}_{2}$ corrected for total lung capacity by single breath (diffusing capacity for $\mathrm{CO}_{2}$ divided by the alveolar volume $\left.-\mathrm{DL}_{\mathrm{CO} / \mathrm{VA}}\right)$ was severely impaired (57\% of predicted value), suggesting a pattern of interstitial disease.

Chest radiography (Photo 1) revealed diffuse signs of interstitial fibrosis with reticular peripheral opacities predominant at lower fields. High resolution computer tomography (Photo 2) identified bilateral, subpleural basal reticular opacities, with associated traction bronchiectasis and honeycombing in absence of any nodules or ground-glass opacities. In the upper lobes, signs of emphysema were identified, without significant air entrapment. Significantly, previous chest radiographies, performed before retirement, appeared as substantially normal. Because of suggestive personal history and radiological signs [20], a diagnosis of the IPF was then indicated.

\section{CASE NO. 2}

An otherwise healthy 73 year-old Caucasian male retired joiner presented with a 3-year history of insidious onset progressive breathlessness and non-productive cough. There was no documented recent history of fever or weight loss. His personal history was negative for pulmonary disorders, but working as a joiner he had complained about frequent episodes of rhino-conjunctivitis, with symptoms increasing from Monday to Friday and improvements after cessation of work. Since his retirement he had been substantially asymptomatic. Ten years ago he received diagnosis of hypertension, and he was treated with $2.5 \mathrm{mg}$ of bisoprolol once a day.

Having been a renter for 10 years, he had worked for a total of 34 years as a high-specialized joiner in several furniture industries in Italy and Western Germany, and his occupational history suggested very high level of exposure during polishing and sawing of hardwood dust (oak, mahogany, beech and pine: available technical reports suggested exposure between $4.8-6 \mathrm{mg} / \mathrm{m}^{3}$ from 1985 and 1990, then reduced to $3.4-4.4 \mathrm{mg} / \mathrm{m}^{3} \mathrm{un}$ til his retirement). Moreover, the patient reported a total of 4 years of employment in a pulp and paper mill in Western Germany, where he was in charge of put coarse cartoons in a mechanical press, then manually refining the borders. All activities were performed under rigorous mechanical ventilation, and chemical treatments were not performed in presence of the patient.

On physical examination, the patient appeared healthy (body weight: $78 \mathrm{~kg}$, height: $165 \mathrm{~cm}$, blood pres- 
a)

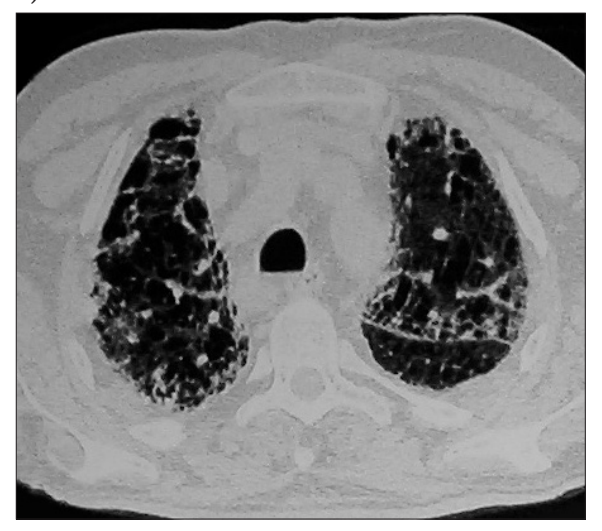

b)

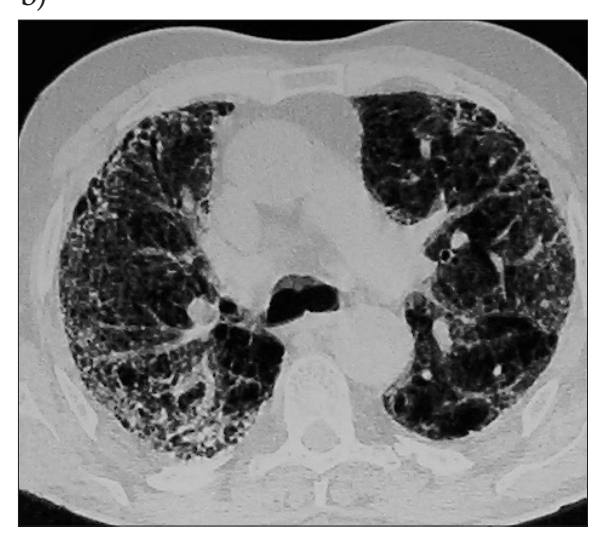

c)

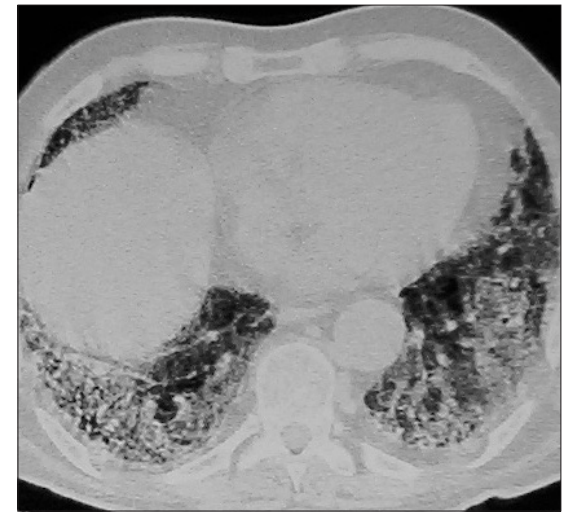

Selected axial slices through the lower lung fields $(a-c)$ show diffuse peripheral reticular opacities in a pattern of distinctive and diffuse honeycombing. As in the 1st case, there were no signs of ground-glass or nodules and an apico-basilar gradient ( $a-c)$ was evident, without sparing of upper zones (a). Moreover, peripheral involvement of lower fields was apparently more diffuse and severe than in the 1st case (confront b and c with Photo $2 \mathrm{~b}$ and c). Panel b and c in particular show a combination of subpleural opacities and diffuse honeycombing with associated architectural distortions along the periphery and lung bases / Wybrane przekroje (a-c) pokazują rozproszone obwodowe siateczkowate zacienienia w postaci charakterystycznego rozproszonego obrazu plastra miodu. Brakuje oznak występowania guzków lub zmian typu matowej szyby jak w przypadku 1., natomiast można zaobserwować szczy towo-podstawny gradient (a-c), obejmujący również górne strefy (a). Ponadto obwodowe zacienienie dolnych pól okazało się bardziej rozproszone oraz intensywniejsze niż w przypadku 1. (por. fotografie $1 \mathrm{~b}$ i 1c z 2b i 2c). Szczególnie przekroje b i c ukazują połączenie podopłucnowych zacienień i rozproszonego obrazu plastra miodu z zaburzeniami struktury płuc u ich podstawy i wzdłuż obwodu.

Photo 3. High resolution computer tomography (HRCT) - case No. 2

Fot. 3. Tomografia komputerowa o wysokiej rozdzielczości - przypadek nr 2

sure: 125/80 mm Hg, pulse: 80 per minute), with no signs of peripheral oedema. Laboratory data showed normal values for blood count and blood chemistry panel. On the other hand, blood gas evaluation revealed mild hypoxemia with respiratory alkalosis $\left(\mathrm{pH}=7,48 ; \mathrm{pCO}_{2}=32.2 \mathrm{~mm} \mathrm{Hg} ; \mathrm{pO}_{2}=59 \mathrm{~mm} \mathrm{Hg}\right.$; $\left.\mathrm{HCO}_{3}{ }^{-}=24.4 \mathrm{mmol} / \mathrm{l}\right)$. Spirometry identified a moderate restrictive pattern $(\mathrm{FVC}=1.831-60 \%$ of predicted value; $\mathrm{FEV}_{1}=1.16-52 \% ; \mathrm{FEV}_{1} / \mathrm{FVC}=63 \% ; \mathrm{PEFR}=1.72 \mathrm{l} / \mathrm{s}$ ) and $\mathrm{DL}_{\mathrm{CO} / \mathrm{vA}}$ was also severely impaired (54\% of predicted value).

Chest radiography showed diffuse interstitial fibrosis with extensive emphysema in the upper lobes. High resolution computer tomography (Photo 3) identified diffuse peripheral reticular opacities in a pattern of distinctive and diffuse honeycombing in the lower fields, with an apico-basilar gradient. In general, radiological findings were compatible with the UIP pattern. Eventually, a diagnosis of the IFP was indicated.

\section{DISCUSSION}

The pulmonary fibrosis is a common feature of several autoimmune or immune mediated disorders (e.g., rheumatoid arthritis, systemic lupus erythematosus, scleroderma, sarcoidosis and Wegener's granulomatosis), and may be induced by inflammatory disorders following inhalation of organic and inorganic dusts (e.g., asbestos, silica). Several drugs, and in particular amiodar- one, bleomycin, busulfan, methrotrexate, nitrofurantoin, may also induce the PF. Actually, clinical and radiological signs and symptoms are insufficient to identify the distinctive aetiology, and a detailed anamnesis is therefore mandatory in order to discriminate between secondary and idiopathic cases [17-19,21,22].

Pathological mechanisms underlying the PF are not well understood, but 4 overlapping mechanisms have been identified in the development of the PF, and they include:

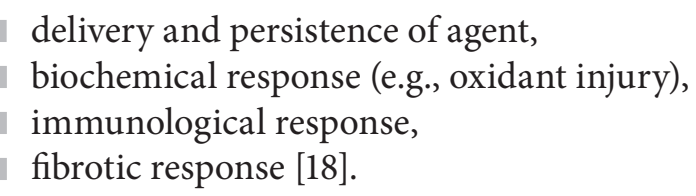

Malignant and non-malignant disorders more strongly associated with WDs exposure such as allergic rhinitis, chronic bronchitis, and asthma are all inflammatory diseases characterized by the infiltration of inflammatory cells ( $\mathrm{T}$ cells, mast cells, basophils, eosinophils, neutrophils, and/or macrophages) to the site of inflammation [23-28].

Research studies have pointed out that acute exposure to WDs is associated with an increased blood count of eosinophils whereas bronchoalveolar lavage (BAL) and nasal lavage (NAL) show an increased cellularity, predominantly neutrophils and T cell lymphocytes, with increased expression of inflammatory mediators [29-32]. At alveolar level, WDs are also able to elicit an intense inflammatory reaction, with high- 
level expression of oxygen and nitrogen reactive species. Wood dusts activated alveolar macrophages and secreted a variety of cytokines and chemokines (MIP2, TNFa, TGF $\beta$, IL1b, CCL2, CCL3, CCL4, CCL8, CCL11, CCL12, CCL17, CCL20, CXCL2/3, CXCL5) involved in the development and maintenance of inflammatory response [33-36].

In other words, there is sufficient experimental evidence hinting that biochemical and immunological properties of WDs may be sufficient to induce an early alveolar epithelial lesion (I), then eliciting a localized and prolonged tissue inflammation (II). The role of inflammation is then pivotal, being followed by a regenerative process with predominant interstitial fibrosis (III). At the moment, there are no genetic factors consistently associated with the IPF but, as a recent case control study suggests, family history of the PF is strongly associated with the increased risk of the IPF $(\mathrm{OR}=6.1$, 95\% CI: 2.3-15.9) [37]. Specific genetic polymorphisms may be associated with a more intense or prolonged activation of inflammation, therefore explaining, on the one hand, a certain heterogeneity of epidemiological data and, on the other hand, the familial clustering of cases [37,38]. Additionally, chronic infections and other environmental factors leading to epithelial injury and apoptosis (e.g., cigarette smoking) might contribute to the IPF pathogenesis, suddenly accelerating an otherwise slowly evolving process [37]. Epidemiological studies evidence that the IPF is of late diagnosis (usually in the early 60-70s) suggesting that, from an early exposure the IPF pathogenesis usually requires several years in order to evolve into a noticeable ILD which in turn may become clinically relevant only after decades, when professional exposure is ended or forgotten $[5,7,10]$.

Despite the consistence of research and epidemiological studies in suggesting WDs as a major risk factor for the PF $[19,22]$, with many cases of the IPF being eventually WD-related PF $[5,6,14,16]$, some caveats should be addressed.

Firstly, both professional exposure to WDs and the IPF are by far not uncommon. Basically, a serendipitous association is therefore not only possible but also even probable. Moreover, despite the available epidemiological studies appear as consistent, the number of analysed cases is relatively small. In the frequently cited meta-analysis of Taskar and Coultas, 58/625 cases (vs. 67/1319 controls) appeared as professionally exposed to wood dusts $[19,22]$ and, summarizing the evidence published to date, epidemiological evidence reside on $94 / 860$ cases vs. $89 / 2190$ controls, with a pooled OR of 2.992 and $95 \%$ CI: $1.889-4.740$, but a moderate heterogeneity $\left(\mathrm{I}^{2}=41 \%\right)$ (Table 1$)$.

Secondly, all published studies about the IPF in WDs professional exposure are retrospective $[19,39]$. In such settings, an accurate measurement of past exposures, including dose and duration is actually very difficult and may be compromised not only because of faulty patient recall but also because of failure of the clinician to systematically inquire about past exposures. In general, the quality in the reconstruction of professional exposures is frequently inconsistent [19], and may lack critical anamnestic remarks such as previous environmental, occupational or personal (i.e., iatrogenic) exposures able to induce the PF.

Exposure assessment is particularly critical because professional exposure to WDs is most frequently and precisely a co-exposition with other well-known risk factors for the PF, such as silica or formaldehyde. In this case wood dust would not directly induce the PF, rather prolonging and enhancing tissue inflammation or it may be of only residual relevance in the pathogenesis of the PF $[3,4,7]$.

Finally, the diagnosis (clinical, radiological or histological one) of the IPF should also be critically analysed. Wood dusts and their contaminants might elicit immune related disorders such as extrinsic allergic alveolitis (EAA): being interstitial inflammation and fibrosis, a common end point for both disorders is that the IPF may be a misdiagnosis. This latter point is particularly critical, stating that signs of the EAA may be identified up to $10 \%$ of woodworkers [7,40-43].

In the 2 case reports we present here, a histological diagnosis of the IPF was not available. Stating the age of patients (respectively, 83 and 73 years), invasive procedures such as the BAL and pulmonary biopsies were not performed, and diagnosis resided only on clinical and radiological features. Epidemiology of the IPF suggests that in many cases histological diagnosis may be unavailable and diagnostic criteria arising from ATS/ERS/JRS/ALAT statement of 2011 also admit that case definition may reside only on the HRCT identification of the UIP pattern among patients, in the cases of which other secondary causes where excluded [9]. In both cases, not only the patients' personal histories were negative for other autoimmune or immune mediated disorders, but also for environmental/personal exposure otherwise associated for the increased risk of the PF.

Regarding smoking habit, the 2 nd case was a lifelong non-smoker and the 1st case had a very remote history of smoking, with a relatively low cumulative exposure. 
Occupational history of both patients documented previous professional exposure to wood dust: exposure assessment was available (although fragmentary) and suggested that the 1st case was exposed to relatively low levels of WDs, compatible with average exposure in Italian wood industry [44], whereas the 2 nd case had a cumulatively shorter but also more intense exposure. In the latter case, a possible exposure to allergens or risk factors for the EAA during his activity in the pulp and paper mill could not be ruled out. However, this exposure was short (in total, 4 years), remote and his previous personal history was totally negative for signs or symptoms of pulmonary disorders.

Interestingly, the 2 nd case had a personal history of rhino-conjunctivitis, with symptoms showing a consistent work related trend. These remarks may explain, in a classical context of long clinical latency $[5,7,10,14,16]$, why the 2 nd case had an early diagnosis with a more profuse pulmonary involvement: not only the former could have beneficed from lesser exposure to the WDs, but in the 2 nd case a personal predisposition to higher reactivity for WDs could be suspected.

\section{CONCLUSIONS}

The cases we presented here received a radiological diagnosis of the IPF: in both cases an occupational history of prolonged exposure to WDs was evidenced, suggesting a causal relationship. Epidemiological evidence $[10,19,22]$ suggests that many cases of the IPF could actually be WDs-related PF, and several national workers compensation authorities (e.g., France) offer specific compensation. Because WDs-related PF cases lack any pathognomonic sign able to discriminate them from "true" idiopathic cases, a correct diagnosis is totally based on an accurate anamnesis, requiring a detailed reconstruction of clinical history and past professional or environmental exposures. Unfortunately, exposure reconstruction is frequently inconsistent and anamnesis often misses other causes of pulmonary fibrosis (e.g., extrinsic allergic alveolitis) [39].

\section{ACKNOWLEDGMENTS}

The author wishes to express his sincere gratitude to Dr. Simone Cella (Academic Hospital of Parma, Diagnostic Department, Pediatric Radiology Unit) for his discrete and kind support necessary to a better evaluation and interpretation of the iconographic material, and for making available the follow-up images.

\section{REFERENCES}

1. Kauppinen T, Vincent R, Liukkonen T, Grzebyk M, Kauppinen A, Welling I, et al. Occupational exposure to inhalable wood dust in the member states of the European Union. Ann Occup Hyg. 2006;50(6):549-61, http:// dx.doi.org/10.1093/annhyg/mel013.

2. Demers PA, Boffetta P, Kogevinas M, Blair A, Miller BA, Robinson CF, et al. Pooled reanalysis of cancer mortality among five cohorts of workers in wood-related industries. Scand J Work Environ Health. 1995;21(3):179-90, http://dx.doi.org/10.5271/sjweh.26.

3. Jacobsen G, Schaumburg I, Sigsgaard T, Schlünssen V. Non-malignant respiratory disease and occupational exposure to wood dust. Part I. Fresh wood and mixed wood industry. Ann Agric Enrivon Med. 2010;17:15-28.

4. Jacobsen G, Schaumburg I, Sigsgaard T, Schlünssen V. Non-malignant respiratory disease and occupational exposure to wood dust. Part II. Dry wood industry. Ann Agric Enrivon Med. 2010;17:29-44.

5. Hubbard R. Occupational dust exposure and the aetiology of cryptogenic fibrosing alveolitis. Eur Respir J. 2001;18(S32):119-21.

6. Hubbard R, Lewis S, Richards K, Johnston I, Britton J. Occupational exposure to metal or wood dust and aetiology of cryptogenic fibrosing alveolitis. Lancet. 1996;347: 284-9, http://dx.doi.org/10.1016/S0140-6736(96)90465-1.

7. Baumgartner KB, Samet JM, Coultas DB, Stidley CA, Hunt WC, Colby TV, et al. Occupational and environmental risk factors for idiopathic pulmonary fibrosis: A multicenter case-control study. Am J Epidemiol. 2000;152(4): 307-15, http://dx.doi.org/10.1093/aje/152.4.307.

8. Behr J, Hoeper MM, Kreuter M, Klotsche J, Wirtz H, Pittrow D. Investigating significant health trends in idiopathic pulmonary fibrosis (INSIGHTS-IPF): Rationale, aims and design of a nationwide prospective registry. BMJ Open Respir Res. 2014;1(1):e000010, http://dx.doi. org/10.1136/bmjresp-2013-000010.

9. Raghu G, Collard HR, Egan JJ, Martinez FJ, Behr J, Brown KK, et al. An official ATS/ERS/JRS/ALAT statement: Idiopathic pulmonary fibrosis: Evidence-based guidelines for diagnosis and management. Am J Respir Crit Car. 2011;183(6):788-824, http://dx.doi.org/10.1164/ rccm.2009-040GL.

10. Ley B, Collard H. Epidemiology of idiopathic pulmonary fibrosis. Clin Epidemiol. 2013;5:483-92, http://dx.doi. org/10.2147/CLEP.S54815.

11. Hutchinson JP, McKeever TM, Fogarty AW, Navaratnam V, Hubbard R. Increasing global mortality from idiopathic pulmonary fibrosis in the 21st century. 
Ann Am Thorac Soc. 2014;11(8):1176-85, http://dx.doi. org/10.1513/AnnalsATS.201404-145OC.

12. Demedts M, Wells AU, Antó JM, Costabel U, Hubbard R, Cullinan P, et al. Interstitial lung diseases: An epidemiological overview. Eur Respir J. 2001;18(S32):2s-16s.

13. Coultas DB, Zumwalt RE, Black WC, Sobonya RE. The epidemiology of interstitial lung diseases. Am J Respir Crit Car. 1994;150(4):967-72, http://dx.doi.org/10.1164/ ajrccm.150.4.7921471.

14. Scott J, Johnston I, Britton J. What causes cryptogenic fibrosing alveolitis? A case-control study of environmental exposure to dust. BMJ. 1990;301:1015-7, http://dx.doi. org/10.1136/bmj.301.6759.1015.

15. Gustafson T, Dahlman-Höglund A, Nilsson K, Ström K, Tornling G, Torén K. Occupational exposure and severe pulmonary fibrosis. Respir Med. 2007;101(10):2207-12, http://dx.doi.org/10.1016/j.rmed.2007.02.027.

16. Mullen J, Hodgson MJ, DeGraff A, Godar T. Case-control study of idiopathic pulmonary fibrosis and environmental exposures. J Occup Environ Med. 1998;40(4):363-7, http://dx.doi.org/10.1097/00043764-199804000-00011.

17. Awadalla NJ, Hegazy A, Elmetwally RA, Wahby I. Occupational and environmental risk factors for idiopathic pulmonary fibrosis in Egypt: A multicenter case-control. Int J Occup Environ Med. 2012;3(3):107-16.

18. Miyake Y, Sasaki S, Yokoyama T, Chida K, Azuma A, Suda $\mathrm{T}$, et al. Occupational and environmental factors and idiopathic pulmonary fibrosis in Japan. Ann Occup Hyg. 2005;49(3):259-65, http://dx.doi.org/10.1093/annhyg/ meh090.

19. Taskar V, Coultas DB. Is idiopathic pulmonary fibrosis an environmental disease? Proc Am Thorac Soc. 2006;3(4): 293-8, http://dx.doi.org/10.1513/pats.200512-131TK.

20. Pinheiro GA, Antao VC, Wood JM, Wassell JT. Occupational risk for idiopathic pulmonary fibrosis mortality in the United States. Int J Occup Environ Health. 2008;14(2):117-23, http://dx.doi.org/10.1179/oeh. 2008.14.2.117.

21. Souza CA, Müller NL, Flint J, Wright JL, Churg A. Idiopathic pulmonary fibrosis: Spectrum of high-resolution CT findings. Am J Roentgenol. 2005;185(6):1531-9, http://dx.doi.org/10.2214/AJR.04.1599.

22. Taskar V, Coultas D. Exposures and idiopathic lung disease. Semin Respir Crit Care Med. 2009;29(6):670-9, http://dx.doi.org/10.1055/s-0028-1101277.

23. Chan-Yeung M. Mechanism of occupational asthma due to western red cedar (Thuja plicata). Am J Ind Med. 1994;25:13-8, http://dx.doi.org/10.1002/ajim.4700250106.

24. Li DH, Yuan L, Yi SL, Jiang ZH. Effects of wood dust exposure on respiratory health: Cross-sectional study among farmers exposed to wood dust. Am J Ind Med. 1990;17:84-5, http://dx.doi.org/10.1002/ajim.4700170123.

25. Mandryk J, Alwis UK, Hocking AD. Effects of personal exposures on pulmonary functionand work-related symptoms among sawmill workers. Ann Occup Hyg. 2000; 44(4):281-9, http://dx.doi.org/10.1093/annhyg/44.4.281.

26. Hytönen M, Kanerva L, Malmberg H, Martikainen R, Mutanen P, Toikkanen J. The risk of occupational rhinitis. Int Arch Occup Environ Heaalth. 1997;69:487-90, http://dx.doi.org/10.1007/s004200050178.

27. Owen C. Chemokine receptors in airway disease: Which receptors to target? Pulm Pharmacol Ther. 2001;14(3): 193-202, http://dx.doi.org/10.1006/pupt.2001.0281.

28. McSharry C, Anderson K, Bourke SJ, Boyd G. Takes your breath away - The immunology of allergic alveolitis. Clin Exp Immunol. 2002;128:3-9, http:/dx.doi.org/10.1046/ j.1365-2249.2002.01849.x.

29. Johard U, Eklund A, Dahlqvist M, Ahlander A, Alexandersson R, Eklholm U, et al. Sign of alveolar inflammation in non-smoking Swedish wood trimmers. Br J Ind Med. 1992;49:428-34, http://dx.doi.org/10.1046/ j.1365-2249.2002.01849.x.

30. Dahlqvist M, Palmberg L, Malmberg P, Sundblad B-M, Ulfvarsson U, Zhiping W. Acute effects of exposure to air contaminants in a sawmill on healthy volunteers. Occup Environ Med. 1996;53:586-90, http://dx.doi.org/10.1136/ oem.53.9.586.

31. Ahman M, Hage-Hamsten M, Johansson SGO. IgE-mediated allergy to wood dusts probably does not explain the high prevalence of respiratory symptoms among Swedish woodwork teachers. Allergy. 1995;50(7):559-62, http://dx.doi.org/10.1111/j.1398-9995.1995.tb01199.x.

32. Gripenback S. Accumulation of eosinophils and T-lymphocytes in the lungs after exposure to pinewood dust. Eur Respir J. 2005;25(1):118-24, http://dx.doi.org/10.118 3/09031936.04.00059804.

33. Määttä J, Luukkonen R, Husgafvel-Pursiainen K, Alenius $\mathrm{H}$, Savolainen K. Comparison of hardwood and softwood dust-induced expression of cytokines and chemokines in mouse macrophage RAW 264.7 cells. Toxicology. 2006;218(1):13-21, http://dx.doi.org/10.1016/j.tox. 2005.09.001.

34. Määttä J, Majuri M-L, Luukkonen R, Lauerma A, Husgafvel-Pursiainen $\mathrm{K}$, Alenius $\mathrm{H}$, et al. Characterization of oak and birch dust-induced expression of cytokines and chemokines in mouse macrophage RAW 264.7 cells. Toxicology. 2005;215(1-2):25-36, http://dx.doi. org/10.1016/j.tox.2005.06.021.

35. Bornholdt J, Saber AT, Sharma AK, Savolainen K, Vogel U, Wallin $\mathrm{H}$. Inflammatory response and genotoxicity of 
seven wood dusts in the human epithelial cell line A549. Mutat Res. 2007;632:78-88, http://dx.doi.org/10.1016/ j.mrgentox.2007.04.016.

36. Pylkkänen L, Stockmann-Juvala H, Alenius H, Husgafvel-Pursiainen K, Savolainen K. Wood dust induces the production of reactive oxygen species and caspase-3 activity in human bronchial epithelial cells. Toxicology. 2009;262:265-70, http://dx.doi.org/10.1016/j.tox. 2009.06.019.

37. García-Sancho C, Buendía-Roldán I, Fernández-Plata MR, Navarro C, Pérez-Padilla R, Vargas MH, et al. Familial pulmonary fibrosis is the strongest risk factor for idiopathic pulmonary fibrosis. Respir Med. 2011;105(12): 1902-7, http://dx.doi.org/10.1016/j.rmed.2011.08.022.

38. King ET, Pardo A, Selman M. Idiopathic pulmonary fibrosis. Lancet. 2011;378:1949-61, http://dx.doi. org/10.1016/S0140-6736(11)60052-4.

39. Glazer CS, Newman LS. Occupational interstitial lung disease. Clin Chest Med. 2004;25(3):467-78, http:// dx.doi.org/10.1016/j.ccm.2004.04.004.
40. Lacasse Y, Girard M, Cormier Y. Recent advances in hypersensitivity pneumonitis. Chest J. 2012;142(1):1189-90, http://dx.doi.org/10.1378/chest.11-2479.

41. Halpin DMG, Graneek BJ, Turner-Warwick M, Newman Taylor AJ. Extrinsic allergic alveolitis and asthma in a sawmill worker: Case report and review of the literature. Occup Environ Med. 1994;51:160-4, http://dx.doi. org/10.1136/oem.51.3.160.

42. Halpin DMG, Graneek BJ, Lacey J, Nieuwenhuijsen MJ, Williamson PAM, Venables KM, et al. Respiratory symptoms, immunological responses, and aeroallergen concentrations at a sawmill. Occup Environ Med. 1994;51: 165-72, http://dx.doi.org/10.1136/oem.51.3.165.

43. Enarson DA, Chan-Yeung M. Characterization of health effects of wood dust exposures. Am J Ind Med. 2013; 17(1):33-8, http://dx.doi.org/10.1002/ajim.4700170107.

44. Scarselli A, Binazzi A, Ferrante P, Marinaccio A. Occupational exposure levels to wood dust in Italy, 1996-2006. Occup Environ Med. 2007;65(8):567-74, http://dx.doi. org/10.1136/oem.2007.036350.

This work is licensed under a Creative Commons Attribution-NonCommercial 3.0 Unported License / Ten utwór jest dostępny na licencji Creative Commons Uznanie autorstwa - Użycie niekomercyjne 3.0 Unported - https://creativecommons.org/licenses/by-nc/3.0/deed.en. 